\title{
MACHADO EM QUADRINHOS: ASPECTOS DISCURSIVOS DE UMA TRADUÇÃO INTERSEMIÓTICA
}

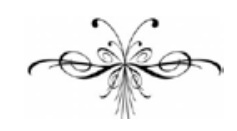 \\ Lucas Piter Alves Costa
}

Resumo: O objetivo deste trabalho é apontar alguns aspectos discursivos da obra de tradução intersemiótica em quadrinhos d'O Alienista, conto de Machado de Assis, publicada em 2007 por Fábio Moon e Gabriel Bá. Trata-se de mostrar como o texto da história em quadrinhos foi elaborado e quais os efeitos de sentido que tal elaboração proporcionou. A base teórica deste trabalho se encontra na Análise do Discurso. O presente trabalho aborda pontos como a semiótica da história em quadrinhos d'O Alienista; algumas questões sobre narrativa em quadrinhos; a caracterização do personagem Simão Bacamarte; e a heterogeneidade enunciativa na história em quadrinhos de Moon e Bá, como forma de buscar uma identidade discursiva para $\mathrm{O}$ Alienista em quadrinhos. Os resultados apontam como Moon e Bá engendram uma obra nova através do trabalho com a linguagem dos quadrinhos, e como a identidade d'O Alienista se forma a partir da relação interdiscursiva.

Palavras-chave: Tradução intersemiótica; O Alienista; História em quadrinhos.

\begin{abstract}
The objective of this study is to show some discursive aspects of the work of intersemiotic translation in comic of the O Alienista, Machado de Assis' tale, published in 2007 by Fabio Moon and Gabriel Ba. It intends to show how the text of the comic book was elaborated and what the effects of meaning that this elaboration has afforded. The theoretical basis of this work is in Discourse Analysis. This study approaches points as the semiotics of comics of $\mathrm{O}$ Alienista; some questions about narrative comic; the constructing of character Simão Bacamarte; and the enunciative heterogeneity in the Moon and Ba's comic book, as a way to seek a discursive identity for the $\mathrm{O}$ Alienista comic book. The results indicate that Moon and $\mathrm{Ba}$ create a new work by working with the language of comics, and how the identity of the $\mathrm{O}$ Alienista is formed from interdiscursive relation.
\end{abstract}

Keywords: Intersemiotic translation; O Alienista; Comics. 
$\mathrm{D}$ urante um longo período, sobretudo em meados dos anos 1960, os Quadrinhos foram considerados como objetos de leitura "inferiores", por vezes direcionados a um público "inapto" a consumir obras literárias. Mesmo com as obras da série Classics Ilustrated, não houve reconhecimento considerável de sua linguagem como forma artística ou literária: as adaptações eram vistas apenas como clássicos ilustrados, não como obras capazes de se legitimar. Este tipo de visão teve seu fundamento: os recursos de linguagem dos quadrinhos ainda não haviam se modificado a ponto de serem reconhecidos como linguagem artística. Na época da série supracitada, a junção de palavras e imagens ou era ainda considerada como diversão para as massas ou era um produto do comercialismo crasso (McCLOUD, 1995).

Esse quadro mudou consideravelmente, e hoje podemos encontrar obras de quadrinhos nas escolas. Atrelado a esse fato, temos acompanhado um crescimento de traduções intersemióticas ${ }^{1}$ de obras literárias para quadrinhos. Dentre elas, interessanos a tradução do conto $O$ Alienista, de Machado de Assis, feita pelos quadrinistas Fábio Moon e Gabriel Bá. Publicada pela Editora Agir, a adaptação abre a série Grandes Clássicos em Graphic Novel. O lançamento da graphic novel aconteceu no dia 26 de abril de 2007, em São Paulo.

Assim, nosso objetivo com este trabalho é apontar alguns aspectos dessa obra de tradução intersemiótica. Trata-se de mostrar como o texto da história em quadrinhos foi elaborado e quais os efeitos de sentido que tal elaboração proporciona. Não se trata de uma análise comparada, embora haja eventuais comparações. A comparação não se instala aqui como método ou objetivo de análise. Ela é consequência da busca por um efeito de sentido que existe justamente por relações interdiscursivas. A primazia do interdiscurso, tal como nos diz Maingueneau (1997), faz crer que sempre haverá uma relação entre o Outro e o Mesmo ${ }^{2}$, quer seja em uma análise comparada pari passu ou não.

\section{Um trabalho de escolhas}

O trabalho de tradução literária estabelece uma relação com a história contada. O que é possível constatar com a comparação do tempo ficcional das duas obras (que é, basicamente, uma comparação no nível do texto) é que a estrutura do discurso se alterou, mas a estrutura da história permaneceu, ou seja, a maneira de dizer mudou, mas a história continuou a mesma: a história de Simão Bacamarte, o alienista. As restrições formais de uma história em quadrinhos levaram os autores a mudar o tipo de narrador.

\footnotetext{
${ }^{1}$ Optamos pelo termo "tradução intersemiótica" pelo fato de ele conter uma ideia mais ampla de tradução (em relação à ideia que se tem sobre tradução interlinguística). A tradução intersemiótica é uma interpretação de signos verbais por meio de signos de sistemas não-verbais. Ela pressupõe recriação ou interpretação criativa, muito coerente com a concepção de graphic novel e não carrega os preconceitos que a palavra "adaptação" traz. (BASSNETT, 2003).

2 Esse “Outro", com maiúscula, e sua contraparte, o "Mesmo”, indicam posicionamento discursivo (cf. MAINGUENEAU, 1997). Não se trata, evidentemente, do homônimo lacaniano, mas se insere nos pressupostos sobre heterogeneidade enunciativa e interdiscurso sobre os quais se apoia este trabalho.
} 
Todas as mudanças na adaptação levaram em conta a diferença de ritmo de leitura de uma prosa e de uma História em Quadrinhos. A narração nessa adaptação não era tão importante, e muito dela foi transformada em imagens ou diálogos, então a figura do narrador, tão proeminente no texto original, não tinha o mesmo peso na adaptação. (MOON, 2010, p. 129).

Como disseram Costa e Lopes (2009) acerca da tradução intersemiótica d'O Alienista machadiano para graphic novel, a prática da tradução de uma obra para outra linguagem faz transparecer a natureza da matriz original das duas linguagens, e seu estudo comparado revela ainda as estruturas discursivas em dimensões que uma análise individual poderia não alcançar.

É no nível textual que vai ocorrer a mudança não só do modo de narrar, mas da figura do próprio narrador, uma vez que, em obras impressas, esse é um elemento do texto, um personagem, uma função ou estratégia textual, ou ainda um fragmento/desdobramento do sujeito (COSTA, 2010). A utilização de procedimentos de técnica narrativa que afetam a figura do narrador tende a estar de acordo com o projeto de escritura do autor no nível discursivo. Segundo Costa (2010) e Nunes (1988), os procedimentos de técnica narrativa são componentes da narração, do discurso, e não da história. Por exemplo, ao indagar a Fábio Moon por que ele optou por não dividir a história em capítulos, como no conto machadiano, ele respondeu que:

Nomear cada capítulo e dividir a obra [...] significa utilizar um espaço da página para isso. Na prosa, não faz muita diferença começar um capítulo no meio de uma página, nem faz diferença terminar o capítulo no meio da página e deixar o resto em branco, pulando para a próxima no começo do próximo capítulo, pois o "espaço" da história é o da mente do leitor. Na página, estão apenas as palavras. Na História em Quadrinhos, o espaço da história acontece na página, na virada de página, no tamanho e na composição dos quadrinhos. Nós tínhamos um limite de páginas para fazer a adaptação, e para nós, dividir a HQ em capítulos significaria quebrar o ritmo da leitura das páginas de maneira desnecessária. O mais importante na leitura é envolver o leitor e a quebra do ritmo de leitura o distrai, o afasta do universo da história, então acabamos abandonando a divisão visual dos capítulos. (MOON, 2010, p. 128).

Nos quadrinhos, dentre muitos elementos específicos de sua linguagem, vemos que o principal deles consiste no quadro, ou melhor, no espaço entre os quadros, a sarjeta. ${ }^{3}$ É na passagem de um quadro a outro que ocorre toda construção de significados, e a manipulação desse recurso compõe o savoir-faire do quadrinista, que será colocado em prática de acordo com as restrições situacionais e discursivas, como o limite de páginas ou a mudança de narrador.

A aprendizagem da linguagem só pode ser feita pela apropriação progressiva das formas de uso, formas repetitivas que se tornam rotineiras e se fixam em "maneiras de dizer". Mas como [...] maneiras de dizer dependem da situação de comunicação, a "rotinização" [...] se configura em formas que fazem eco

\footnotetext{
${ }^{3}$ Sarjeta (McCLOUD, 1995), calha (EISNER, 1999), ou ainda hiato (CAGNIN, 1975). Seja qual for a nomeação, o sentido é o mesmo: o intervalo entre um quadro e outro, que representa um corte tempoespacial.
} 
nas exigências das restrições situacionais via restrições discursivas. (CHARAUDEAU, 2004, p. 28).

Moon e Bá, durante o processo de tradução intersemiótica, expressaram sua maneira de ver $O$ Alienista, (re)organizando o discurso literário por uma lógica narrativa quadrinística. E, da mesma forma, (re)organizando o próprio discurso quadrinístico, e ainda, o seu próprio savoir faire desse discurso, como podemos notar nas seguintes palavras:

O Alienista foi a história mais difícil que eu já desenhei. Só a ideia brilhante de usar aguada e não somente o preto e branco chapado já acabou duplicando o tempo da arte final. Além disso, o processo de adaptar o texto do Machado de Assis foi demorado, começando um mês antes do desenho, continuando todos os dias enquanto eu fazia as páginas, e ainda [durou por] duas semanas enquanto eu [fazia] os balões e as cores. (MOON, 2006, web).

O mundo referencial aqui foi o mundo (fictício) criado por Machado de Assis. Mas em outros casos, poderia ser qualquer objeto sobre o qual o sujeitocomunicante quisesse falar. O mundo referencial é aquilo que passou pelo processo de semiotização, tornando-se um discurso, materializado em algum tipo de texto resultante de uma situação de comunicação.

As cinco escolhas básicas elencadas por McCloud (2008) no processo de discursivização quadrinística são imbricadas, não havendo uma ordem préestabelecida entre elas. Embora sejam etapas de qualquer produção em quadrinhos, elas são operadas de modos distintos quando se trata de uma tradução intersemiótica, de uma obra autoral sem um texto fonte literário, de um quadrinho de editora, de uma tirinha, etc. Vejamo-las:

(a) Escolha dos momentos: "Decidir quais momentos incluir em uma história em quadrinhos e quais deixar de fora.” (McCLOUD, 2008, p. 10).

No trabalho de tradução intersemiótica d'O Alienista, essa escolha coincide com os cortes feitos na versão machadiana e com a organização das partes restantes do enredo que foram transformadas em quadrinhos. A escolha dos momentos a narrar coincide ainda com a elaboração de um roteiro, caso ele ainda não exista. Para $O$ Alienista em quadrinhos, a história de Machado serviu como um roteiro, embora ainda tenha sido adaptada novamente para o roteiro de HQ, que especifica o que vai ser desenhado e o que vai ser escrito nos balões e nos recordatários. A seguir, temos um fragmento do conto machadiano. As partes grifadas no fragmento correspondem às partes que foram omitidas no texto quadrinístico. 

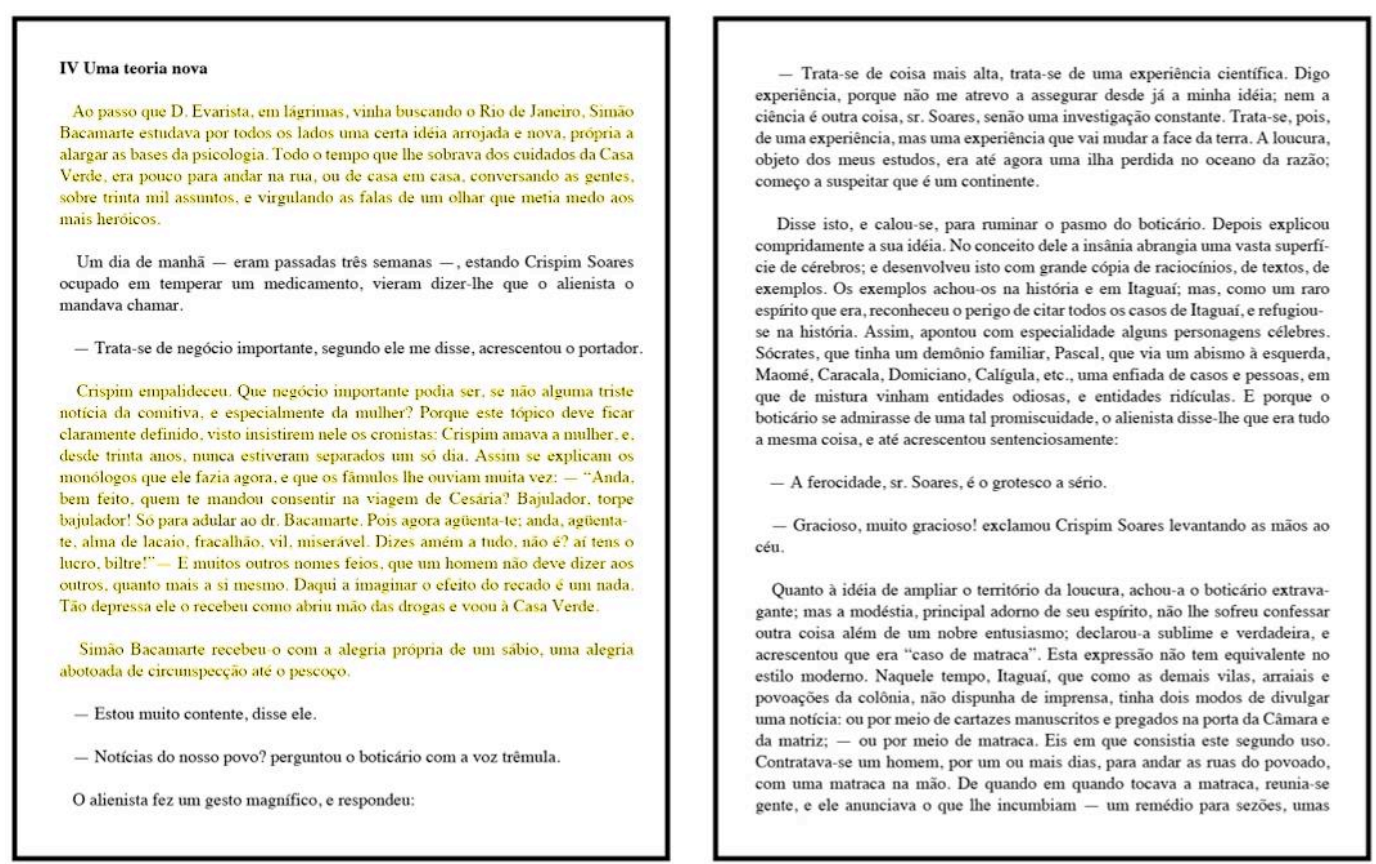

Figura 1: Fragmentos do conto.
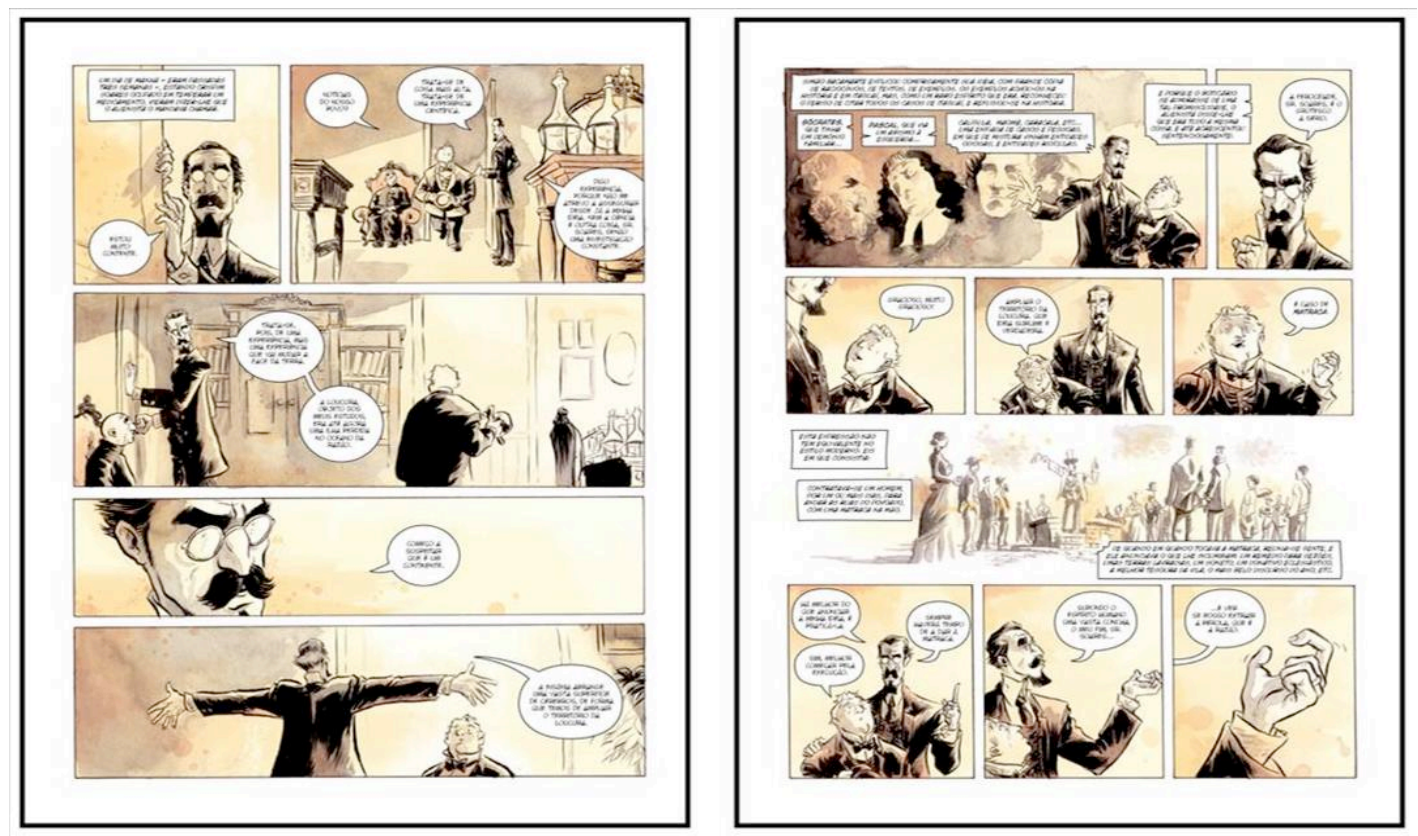

Figura 2: Fragmentos da graphic novel.

A narrativa machadiana não é episódica ou linear. Ela é digressiva. Muitos eventos que se situam em dimensões distintas do tempo e espaço da história são narrados de forma contínua, labiríntica, num movimento, às vezes, de inúmeras retomadas. Dessa forma, os autores optaram por certos cortes para manter o ritmo dinâmico de uma história em quadrinhos.

(b) Escolha do enquadramento: "Escolher a distância e o ângulo corretos para ver esses momentos e onde cortá-los.” (McCLOUD, 2008, p. 10). A distância é categorizada em planos. O ângulo é o ponto de visão do narrador/narratário dentro de um plano. 
"Parece haver consenso entre os diferentes teóricos dos quadrinhos quanto aos tipos de [enquadramentos]" (RAMOS, 2010, p. 136). De acordo com Ramos (2010), os planos são: (1) plano em perspectiva; (2) plano de detalhe, pormenor ou close up (plano fechado); (3) primeiro plano; (4) plano médio ou aproximado; (5) plano americano; (6) plano total ou de conjunto; (7) plano geral ou panorâmico. Os ângulos são: (1) ângulo de visão médio; (2) de visão superior ou plongé; (3) de visão inferior ou contra-plongé.

O enquadramento tem dupla dimensão no processo narrativo: na instância ergo-textual, ele é um procedimento que direciona/condiciona a leitura da história. Também é responsável por um tipo de focalização que faz surgir um tipo de narrador. Na instância textual, o enquadramento é resultado da relação estabelecida entre o olhar do narrador (que passa a ser o olhar do narratário também) e o objeto da diegese.

É como se, à moda machadiana, o narrador quadrinístico dissesse: "Veja isto, caro leitor", ao invés de "Vem comigo, caro leitor". O enquadramento pode aproximar ou distanciar, ocultar ou revelar, e hierarquizar essa relação de saber entre o olhar e o olhado (dependendo do enquadramento, o narrador/narratário pode saber mais ou menos que os personagens). Em outras palavras, o enquadramento situa e/ou posiciona o leitor. Por meio dele, estabelece-se uma relação interpessoal (embora assimétrica) entre os sujeitos do ato de linguagem quadrinístico.

Diferentes enquadramentos podem criar diferentes efeitos de sentidos, sendo impossível elencar todos esses efeitos aqui. O importante é saber que geralmente uma história faz uso de vários enquadramentos, e que, tomados isoladamente, podem ter sentidos distintos daqueles que teriam se tomados no conjunto da história. É por essa razão que a tentativa de extrair algum sentido desses enquadramentos nas histórias em quadrinhos não deve se dar ao molde das análises de discursos publicitários, sobretudo os impressos. Embora a gramática do enquadramento seja a mesma, sua semântica é bem outra.

Alguns efeitos de sentido desses enquadramentos podem ser recorrentes, como são nos casos de planos fechados ou close up, que visam geralmente efeitos patêmicos quando focam a expressão de um personagem como suporte de alguma emoção crucial para a narrativa, como se vê no segundo quadro (Q2) da sequência abaixo $^{4}$, que anuncia a mudança de paradigma do alienista no trato da loucura.

\footnotetext{
${ }^{4}$ A nomenclatura que estabelecemos para fins didáticos sobre a designação dos quadros em um recorte é a seguinte: $Q$ para quadro, seguido de um número que designa sua posição no recorte analisado, não na página da revista. Ex.: Q2 para designar o segundo quadro de uma sequência analisada de dois ou mais quadros. Q2-3 para designar, por exemplo, uma sequência do segundo quadro ao terceiro, numa série recortada para análise de três ou mais quadros. A numeração dos quadros em um recorte é diferente da numeração da página original. Essa nomenclatura será proeminente no capítulo três, mais especificamente na seção sobre as transições de quadro a quadro.
} 


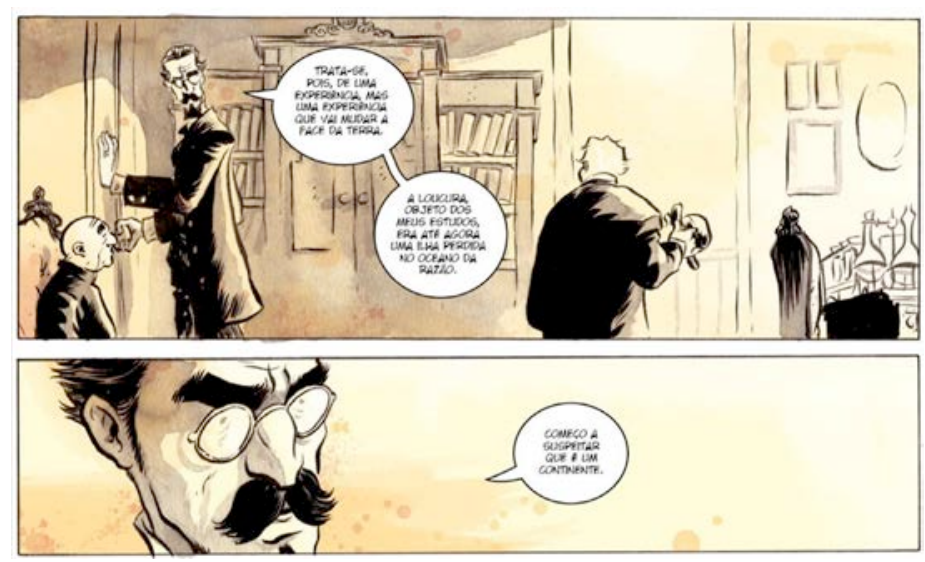

Figura 3: Planos médio e fechado.

Outro exemplo está nos planos panorâmicos a seguir. Com ângulo médio (Q1) e superior (Q2), esses planos distanciam o leitor/narratário, possibilitam transmitir o clima do cenário e situam o personagem.
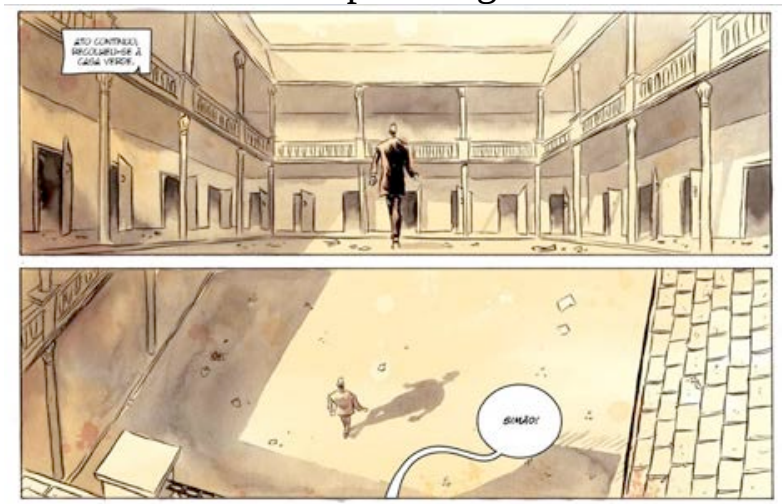

Figura 4: Planos panorâmicos com ângulos médio e superior.

(c) Escolha das imagens: "Representar os personagens, objetos e ambientes com clareza nesses enquadramentos” (McCLOUD, 2008, p. 10).

O autor-escritor lança mão de signos icônicos (ou figurativos) para representar personagens, objetos e ambientes. A representação passa por um trabalho prévio de pesquisa em busca de referências que garantam o estilo de narrativa e contribuam para a verossimilhança, dando um efeito de real. Em entrevista, Moon disse como foi o trabalho de pesquisa sobre $O$ Alienista, trabalho que não se pautou na opinião da crítica:

Nós lemos a obra. Procuramos pelos termos que desconhecíamos, pelas referências que apareciam no texto que eram mais específicas e procuramos encontrar qual era o estilo da história. O resto da pesquisa foi "visual", vendo filmes, desenhos e pinturas da época, procurando uma arquitetura e um vestuário que ajudassem a contar a história. (MOON, 2010, p. 131).

Além do emprego dos signos icônicos, a escolha das imagens passa pelo emprego de signos plásticos, como é o caso das cores e dos traços utilizados n’O Alienista. As imagens são, obviamente, elementos da história, mas as cores e os 
traços, sobretudo quando não estão em uma modalidade mais naturalística, ${ }^{5}$ figuram como elementos extradiegéticos, ou seja, fora do mundo narrado, mas pertencentes ao trabalho da linguagem quadrínistca. Logo, são de domínio exclusivo do autor-escritor (pelo menos é o caso da obra analisada).

(d) Escolha das palavras: "Escolher palavras que acrescentem informações valiosas e se casem bem com as imagens que as rodeiam.” (McCLOUD, 2008, p. 10).

Já dissemos que, n'O Alienista, como se trata de uma tradução intersemiótica, o processo de escolha das palavras coincidiu com o processo de escolha dos momentos a serem desenhados. A consciência dessas escolhas parece estar presente no trabalho de tradução intersemiótica de Moon e Bá, consciência essa que parece se nutrir de um respeito para com a obra machadiana e uma finalidade de demarcar o território dos quadrinhos no cenário cultural:

[...] cabe ao autor saber explorar a sua linguagem pra trazer o que ela tem de melhor à tona e ainda fazer bonito junto à obra adaptada. Cabe ao autor saber analisar o texto original e saber como adaptá-lo, onde cortar, o que manter e o que deve ser acrescentado, saber o que vai virar diálogo e o que se mantém em narração. Não podemos gastar essa boa oportunidade de dar mais visibilidade aos Quadrinhos com trabalhos fracos, adaptações baratas e recortadas. (BÁ, 2007).

As palavras nas histórias em quadrinhos são geralmente empregadas nos balões, nos recordatórios, nas onomatopeias, e em situações no universo diegético. Em construções mais experimentais (diferente d'O Alienista), as palavras podem aparecer como elemento icônico.

(e) Escolha do fluxo: "Guiar os leitores através e entre quadrinhos em uma página” (McCLOUD, 2008, p. 10), ou seja, organizar a disposição dos quadros, sua forma, e dispor os balões e os recordatários. Sempre levando em consideração que no ocidente a direção de leitura é da esquerda para a direita e do alto para baixo (nos quadrinhos japoneses, a direção é diferente). A escolha do fluxo muitas vezes também coincide com a escolha dos enquadramentos, pois a forma do quadro pode direcionar o caminho do olhar. Por exemplo, quadros retangulares estreitos e quadros simétricos direcionam o olhar de formas distintas.

\footnotetext{
${ }^{5}$ Modalidade naturalística é uma categoria extraída da Gramática do Design Visual, de Kress e van Leeuwen (2006). Essa categoria se enquadra na Metafunção Interpessoal, que, como indica o nome, diz respeito à relação entre os sujeitos. A modalidade naturalística, diferente das modalidades sensorial e abstrata, consiste em transmitir um efeito de realismo ou verismo por meio do objeto representado. Utilizamos o termo aqui pelo fato de que, por questão de verossimilhança, os personagens não podem demonstrar ciência dos aspectos plásticos de sua representação, como por exemplo, demonstrar consciência da cor sépia e do traço caricato dos personagens, como n’O Alienista. Em todo caso, acreditamos que a modalidade naturalística pode ocorrer em maior ou menor escala, de acordo com o objeto de comparação. Um exemplo famoso de quadrinho que emprega tal modalidade é a obra Black Orchid, de Neil Gaiman e Dave McKean.
} 


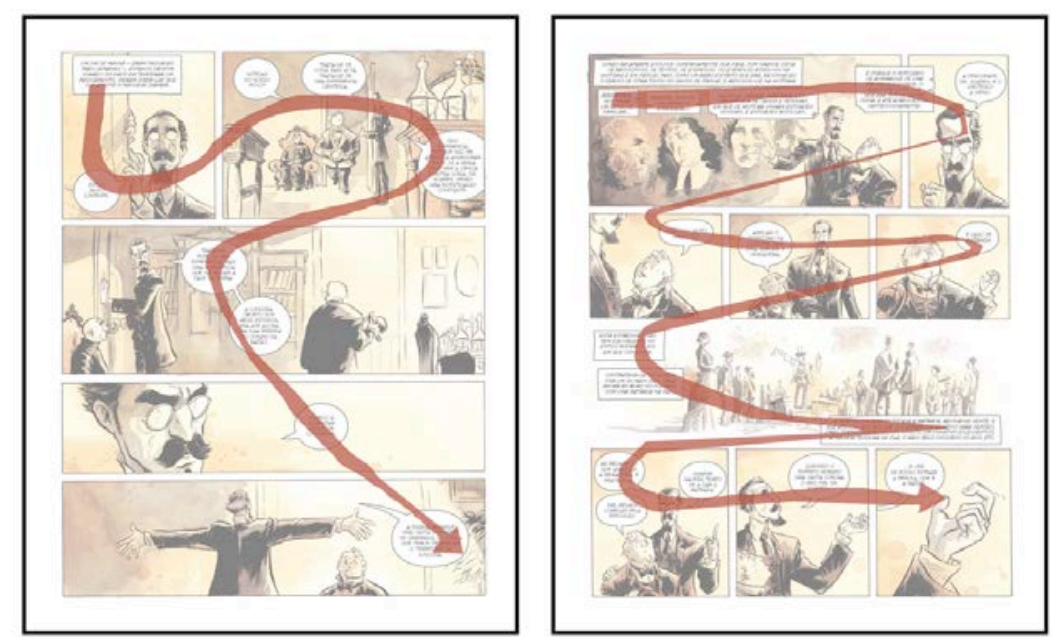

Figura 5: Fluxo sugerido de leitura do estrato verbal.

Trabalhar de forma clara o fluxo de leitura "pode ajudar o público a entrar no mundo de sua história e ir de uma ponta a outra sem ser [...] distraído pelo mundo exterior. [A] narrativa poderá investir todo seu peso na 'história', sem que o 'narrar' obstrua o caminho.” (McCLOUD, 2008, p. 36). Não há garantia alguma sobre a ordem de leitura entre palavras e imagens nos quadrinhos. Então, quanto mais organizada for a diagramação, mais é possível que o ato linguageiro atinja sua finalidade.

Essas escolhas que acabamos de citar fazem parte do que estamos considerando como procedimentos qualificados de técnica narrativa, procedimentos extradiegéticos que constituem "um rol de expedientes retóricos, avalizadores da natureza fictícia do texto, funcionando, portanto, como indicadores do pacto entre o autor implicado [autor-escritor] e o leitor.” (NUNES, 1988, p. 75).

A narrativa d'O Alienista não é imediatista como as narrativas dos quadrinhos americanos e europeus analisados por McCloud (1995). Ela privilegia um tipo de enredo mais presente nos quadrinhos japoneses (embora ainda esteja longe de configurar uma narrativa tipicamente oriental). Além do mais, é permeada por enquadramentos polissêmicos e narração verbal dinâmica, subjetiva, digressiva herdada do texto machadiano que foi mantido -, o que permite o leitor atuar melhor na construção daquilo que não é mostrado. A imposição do texto machadiano sobre o trabalho de tradução intersemiótica parece transparecer na fala de Gabriel Bá ao comentar a ausência de diálogo característica d'O Alienista machadiano:

Machado de Assis é um cara que narra muito, descreve muito as coisas e a gente tinha que ter uma fala de vez em quando. Muito do que era descrito a gente mostrou em imagens. Então nosso estilo foi importante nisso: saber o que podia transformar em imagem e saber aproveitar o texto ao máximo. (MOON \& BÁ, 2007b, entrevistados por FLORO).

O fato de o texto machadiano quebrar o ritmo da história acaba por se relacionar de maneira muito própria com o estrato visual da narrativa em quadrinhos. Diferente das narrativas românticas, voltadas para ação, as narrativas machadianas, com suas tradicionais digressões, possibilitam criar inúmeras cenas sobrepostas em um único trecho. 


\begin{abstract}
Algumas passagens davam novas camadas à história, e foram mantidas. Outras somente reforçavam o "estilo" do texto, quebrando o ritmo da história sem quebrar o ritmo da leitura, que é uma característica maravilhosa da prosa. Como funcionam de maneira diferente nos Quadrinhos, algumas passagens foram transformadas em imagens ou cortadas. (MOON, 2010, p. 130).
\end{abstract}

O Alienista machadiano tem poucas ações descritas e poucas falas de personagens. Não é como nas obras aventurescas do romantismo, cuja ação é dinâmica. Isso refletiu na versão em quadrinhos, que não é como as histórias de superheróis, que também privilegiam a ação, fazendo uso de recursos narrativos que garantam o ritmo acelerado da história.

A polissemia dos estratos verbal e visual que compõem a linguagem d'O Alienista em quadrinhos está marcada no texto através de inúmeras maneiras: pelas imagens mudas, sem falas de personagens ou do narrador; pelas relações instituídas entre narração verbal e visual (por vezes, sendo relações de revezamento, que veremos adiante); pelas passagens do texto machadiano que não foram transformadas em imagens e que aludem a episódios anteriores à história do médico alienista; pela ambiguidade própria da história, que pode ser lida com tons de comédia ou de drama, etc.

\title{
Traduzindo palavras $\mathbf{e}(\mathrm{m})$ imagens
}

No plano das imagens, os recursos expressivos utilizados para singularizar um personagem - posições, gestos, fisionomias, vestimentas, etc. - contribuem para delimitar e/ou reforçar um conceito sobre ele. É o que acontece constantemente nas adaptações cinematográficas. Gomes (2004) disse que, no cinema, a palavra tem papel preponderante na constituição de um personagem, mas a cristalização se dá definitivamente por um contexto visual. Isso serve para outras artes visuais. Em outras palavras, a leitura dos autores da graphic novel - a visão deles acerca dos actantes do conto - pode criar ou recriar conceitos que ora partiriam primordialmente dos leitores da obra original. A utilização de recursos visuais acrescenta sentidos outros, ora revezados ora ancorados nessa relação entre palavras e imagens.

\begin{abstract}
Manifestada sob a espécie de um conjunto descontínuo de marcas, a personagem é uma unidade difusa de significação, construída progressivamente pela narrativa [...]. Uma personagem é, pois, o suporte das redundâncias e das transformações semânticas da narrativa, é constituída pela soma das informações facultadas sobre o que ela é e sobre o que ela faz. (HAMON, 1983 apud REIS \& LOPES, 1988, p. 216).
\end{abstract}

Nos quadrinhos, a relação do ser e do fazer de uma personagem está submetida a mecanismos verbo-imagéticos que são gerenciados pelos processos de conclusão, expostos por McCloud (1995). O estrato verbal diz o que o alienista é e faz, o estrato visual mostra o que ele é e faz. Essa propriedade dos quadrinhos muitas vezes os exime de descrever verbalmente os personagens no que diz respeito às suas características físicas. "Essa definição física completa imposta pelo cinema [ou pelo quadrinho] reduz a quase nada a liberdade do espectador [ou leitor] nesse terreno.” (GOMES, 2004, p. 111). 
Perde-se a liberdade de imaginar a figura do personagem nas obras visuais. Mas a tradução intersemiótica é uma negociação. A caracterização das personagens em uma obra imagética tem a faculdade de lhes preservar em maior escala as características psicológicas, pois, por vezes, interpretar/compreender uma emoção vista é mais incerto do que uma emoção dita. De fato, salvaguardando as devidas e propositais ambiguidades, muitas das colocações do texto machadiano que construiriam uma imagem psicológica precisa de Simão Bacamarte foram retiradas na história em quadrinhos, sobretudo por estarem essas colocações na voz do narrador. No conto, por exemplo, a passagem em que o narrador onisciente diz que Simão amava a mulher contribui para que o leitor acredite nisso, diferente das passagens em que o narrador apenas transmite as impressões dos personagens acerca de Simão.

No que tange ao personagem, podemos dizer que esse processo de tradução intersemiótica da narração em prosa para narração visual é uma espécie de tradução dramática, pois o quadrinista precisa representar por signos visuais as imagens que sua leitura suscitou, criando toda uma mensagem cenográfica, com figurino, gestos, ambientação e até entoação, possível de se variar alterando a tipografia das falas.

A questão mais importante na análise da tradução dramática dos textos de Machado de Assis para as artes que se utilizam de elementos visuais (quadrinhos, cinema, teatro) não é mostrar quais as leituras que esses textos possibilitam. Para esse fim, já existem as milhares de teses que comprovam que o texto machadiano tem diversas formas de representação - a ambiguidade cênica em diversos momentos de Dom Casmurro serve como exemplo. O ponto mais importante, então, dessa dramatização em torno do personagem é saber que a tradução intersemiótica é um discurso e significa uma visão dos quadrinistas sobre a figura de Bacamarte.

O texto machadiano é labiríntico, digressivo, envolvente. Sua estrutura complexa permite ao leitor reestruturá-lo constantemente. Haja vista as inúmeras versões em quadrinhos da obra que estamos analisando. A tradução intersemiótica d'O Alienista ou de qualquer outra obra literária para quadrinhos exige que o texto original seja "destruído" e "reconstruído" - e isso é muito mais do que mera transposição semântica, como parece a princípio.

Embora o texto d'O Alienista não seja dramático per se, as dificuldades de tradução das ações dos personagens são similares. Tanto o tradutor interlinguístico quanto o intersemiótico precisam interpretar visualmente (no sentido de formar imagens) os significados da cena antes de passá-los aos seus respectivos signos. Os dois precisam ter em mente o conhecimento contextual da cena e um repertório de representação visual adquirido da experiência de observador (repertório que, no caso de Simão, reforça certos imaginários sociodiscursivos). Assim, o quadrinista, o tradutor de textos dramáticos e o ator compartilham de conhecimentos comuns quando se trata de representação.

Posturas, gestos, vestimenta e objetos ou atributos possuídos caracterizam o personagem por procedimentos visuais, qualificando-o. De acordo com Bremond (1979), "na banda desenhada [outra designação para história em quadrinhos], a significação dos gestos e mímica é fundamentalmente de ordem narrativa” (BREMOND, 1979, p. 138). Desse modo, a caracterização de um personagem no que tange ao seu gestuário empregado na narrativa pode se relacionar com o seu papel na história. Três posturas do alienista são recorrentes na história em quadrinhos: 
1. Com as mãos para trás, e às vezes ao caminhar. Essa postura está associada à vigilância constante do alienista. O alienista é representando assim em inúmeras passagens: quando passeia pela Casa Verde ou pela vila, deixando “correr pela multidão um olhar inquieto e policial” (MOON \& BÁ, 2007, p. 20); quando vai verificar a loucura do albardeiro Mateus; quando esperava a comitiva de sua esposa chegar do Rio de Janeiro; etc.;

2. Com as mãos em ogiva, com os dedos ligados. Postura associada aos pensadores, e aparece na narrativa em situações que mostram o alienista em estado de observância e reflexão, como na situação que a prima do Costa foi interceder por ele; ou no desfecho da história, quando o alienista reflete sobre sua própria situação;

3. Fumando um cachimbo, objeto que ficou consagrado como ícone de esperteza, prontidão, pensamento científico e sagacidade, por seu uso pelo personagem Sherlock Holmes, de Conan Doile. O cachimbo também é um símbolo fálico que teve valor ornamental nos hábitos masculinos do séc. XVIII. O cachimbo podia ser de várias categorias, com adornos diversos, e seu uso era traço distintivo na sociedade burguesa masculina da época.

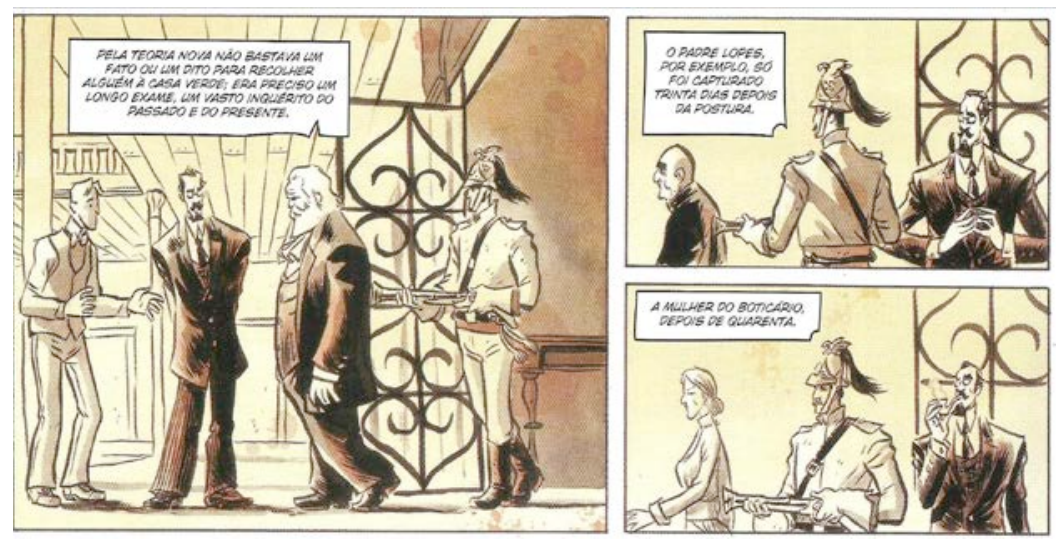

Figura 6: O Alienista. Gestos de Simão. (p. 62).

Comentemos o primeiro caso, das mãos para trás, que é o mais recorrente. De acordo com Pease e Pease (2005), caminhar com a cabeça levantada e com as mãos para trás das costas são gestos comuns nos policiais que percorrem as ruas, do diretor de escola ou de qualquer pessoa que detém autoridade, demonstrando superioridade, vigilância e segurança. 


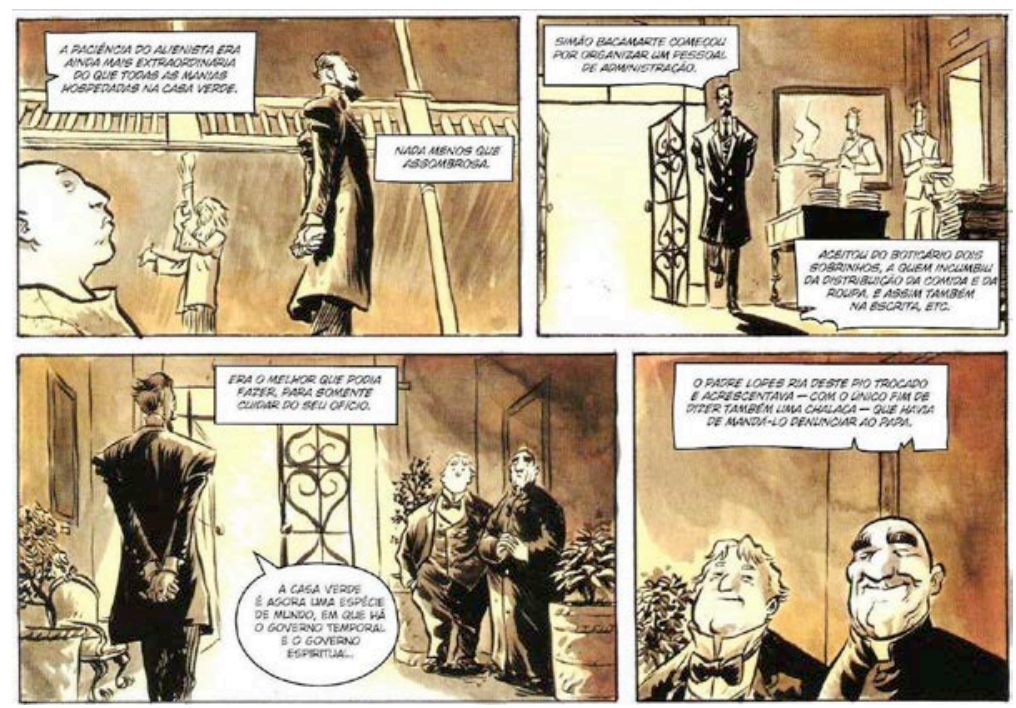

Figura 7: O Alienista. Caminhando. (p. 140).

No Q1 do fragmento acima, além dessa caracterização visual pelo gesto, temos a fala do narrador qualificando o alienista pela sua paciência: “A paciência do alienista era ainda mais extraordinária do que todas as manias hospedadas na Casa Verde. Nada menos que assombrosa.” (MOON \& BÁ, 2007, p. 14, grifos nossos). Aqui, o narrador compara as manias dos loucos com a paciência do alienista, uma forma sutil de dizer que tal atributo era indício de loucura também. No Q1, pela conjugação dos procedimentos, o alienista é autoritário, confiante, vigilante, superior, paciente, extraordinário e assombroso.

De acordo com Eco (1979), apesar das histórias em quadrinhos utilizarem instrumentos próprios na caracterização de um personagem, sua iconografia "nos reporta a estereótipos já realizados em outros ambientes (o cinema, por exemplo)" (ECO, 1979, p. 144). Essa observação se direciona ao personagem Steve Canyon, de Milton Caniff, personagem cuja imagem foi lida pelo teórico como uma mensagem. Tal como Eco (1979) leu a mensagem iconográfica que caracterizava o personagem Steve Canyon, podemos fazer o mesmo com o personagem Simão Bacamarte.

Para Eco (1979), os fatos plásticos ${ }^{6}$ de que o personagem Steve Canyon se reveste assumem uma qualidade de "signo" que reporta, com função hieroglífica, “a uma série de tipos [hollywoodianos], de padrões, de ideias da virilidade que fazem parte de um código conhecido pelos leitores [da época].” (ECO, 1979, p. 137). No caso de Simão Bacamarte, a construção estereotipada do personagem aponta para a imagem, dentre muitas, do cientista detentor de uma inteligência acima do normal (para não dizer anormal). Algumas dessas construções remontam imaginários sociodiscursivos sobre o cientista (leia-se, o cientista louco), por exemplo. "Bacamarte se apresenta como a própria encarnação do clichê do cientista, sobretudo o médico, que o século XIX forjou, sendo a obra de Machado 'criada [...] sob a impregnante influência do espírito científico””. (LIMA, 1991, p. 261).

\footnotetext{
${ }^{6}$ Os fatos plásticos a que Eco (1979) faz referência são os traços que compõem a aparência do personagem, traços que retomam uma série de estereótipos hollywoodianos. Esses fatos plásticos não devem ser confundidos com os signos plásticos que Joly (2007) emprega. Podemos substituir a noção de Eco (1979) pela de estilo, que se refere aos traçados empregados pelo desenhista, ou mesmo pela noção de signo icônico, por esses fatos plásticos representarem valores socialmente cunhados.
} 
Os imaginários sociodiscursivos estão relacionados à ideia de discurso como conjunto de saberes compartilhados e sustentados por um grupo social, estando esses saberes depositados na memória coletiva desse grupo. Os imaginários são formas históricas de saberes. Assim, para Charaudeau (2007):

O imaginário é um modo de apreensão do mundo que nasce da mecânica das representações sociais, com a qual, diz-se, se constrói a significação sobre os objetos do mundo, os fenômenos que nele se produzem, os seres humanos e seus comportamentos, transformando a realidade em real significante. Ele resulta de um processo de simbolização do mundo de ordem afetivo-racional através da intersubjetividade das relações humanas e se deposita na memória coletiva. Assim, o imaginário tem uma dupla função de criação de valores e de justificação das ações. (CHARAUDEAU, 2007, p. 53, tradução nossa). ${ }^{7}$

Os imaginários representam o modo de ver que um grupo social tem de um determinado objeto, fenômeno ou acontecimento social. Vários imaginários podem perpassar um mesmo grupo. E da mesma forma, vários grupos podem compartilhar um mesmo imaginário. Deve-se tomar o cuidado de não delimitar um grupo por um recorte ou seleção de imaginários. Os imaginários não são estanques, eles são engendrados no interdiscurso. Os imaginários podem ser depreendidos dos procedimentos (linguísticos, discursivos, visuais) que compõem o modo de organização descritivo.

A construção estereotipada - aqui já seria melhor dizer: imaginários sociodiscursivos - do alienista acumula atributos que acabam por lembrar outros personagens igualmente estereotipados/representativos que estiveram presentes em outras obras, cujas imagens se perpetuaram em diversos meios semióticos outros:

As imagens engendram palavras que engendram imagens, num movimento sem fim. As imagens alimentam as imagens: encontramos assim filmes que contam histórias de quadros ou de fotografias [ou de personagens da literatura]. A própria publicidade está repleta de citações de outras imagens, de outras publicidades, de obras de arte, de imagens de televisão, de imagens científicas, etc. (JOLY, 2007, p. 121-122).

O uso do ícone do cachimbo, como dissemos, lembra o investigador Sherlock Holmes, personagem que também era possuidor de uma mente científica. Tanto nesse personagem quanto no alienista, o uso do cachimbo reforça a imagem do homem pensante, envolvo interiormente na solução de questões, de enigmas, de problemas que exigem alto grau de pensamento lógico e concentração para serem solucionados. $\mathrm{O}$ ato de fumar, para esses personagens, pode ser tomado como uma maneira de proteger os altos trabalhos mentais da interferência externa do ambiente.

\footnotetext{
${ }^{7}$ No original: L'imaginaire est un mode d'appréhension du monde qui naît dans la mécanique des représentations sociales, laquelle, on l'a dit, construit de la signification sur les objets du monde, les phénomènes qui s'y produisent, les êtres humains et leurs comportements, transformant la réalité en réel signifiant. Il résulte d'un processus de symbolisation du monde d'ordre affectivorationnel à travers l'intersubjectivité des relations humaines, et se dépose dans la mémoire collective. Ainsi, l'imaginaire a une double fonction de création de valeurs et de justification de l'action.
} 
Fumar cigarros, como fumar em cachimbo, é um deslocamento da tensão interna que permite demorar as coisas. Não obstante, o fumante de cigarros toma suas decisões mais rapidamente que o fumante de cachimbo. Na verdade, quem fuma cachimbo precisa de mais tempo que o proporcionado por um cigarro. (PEASE \& PEASE, 2005, p. 50).

Os dois personagens - o primeiro, investigador de crimes, o segundo, de mentes - tomavam suas decisões depois de profundas reflexões e apurações dos fatos.
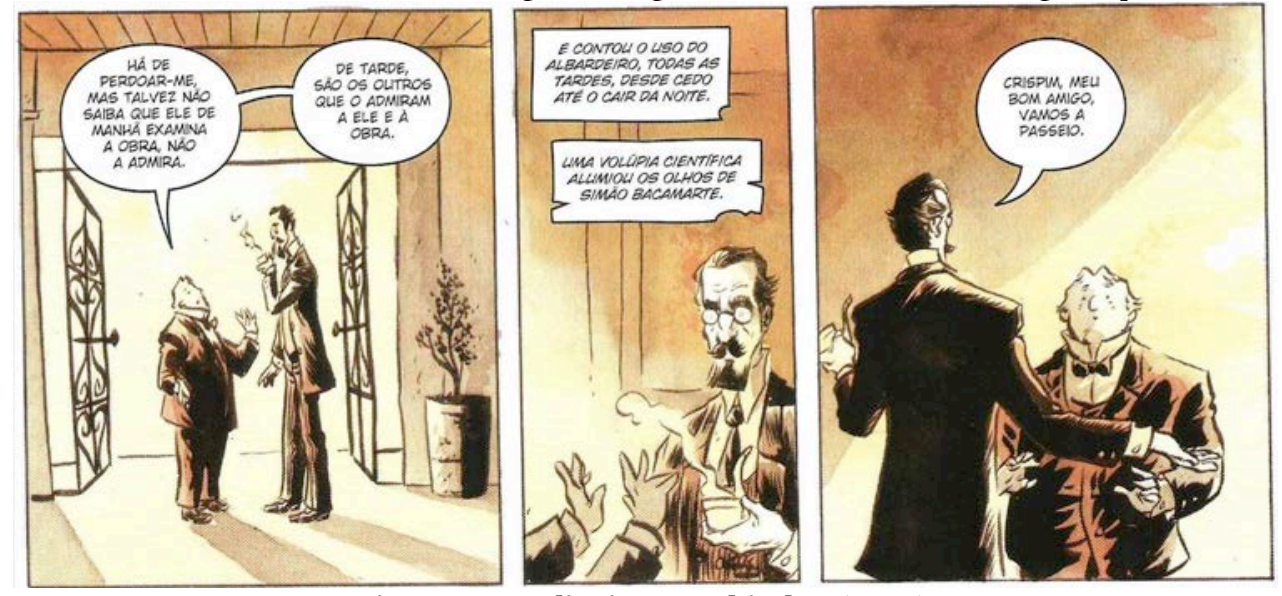

Figura 8: O Alienista. Cachimbo. (p. 28).

E também a aparência física de Simão, associada ao seu fim trágico e à companhia constante do parvo Crispim Soares, direcionam o personagem para a imagem de Dom Quixote - imagem reforçada pela situação em que Simão e Crispim voltavam para casa montados em um cavalo e uma besta ruana (mula), respectivamente.

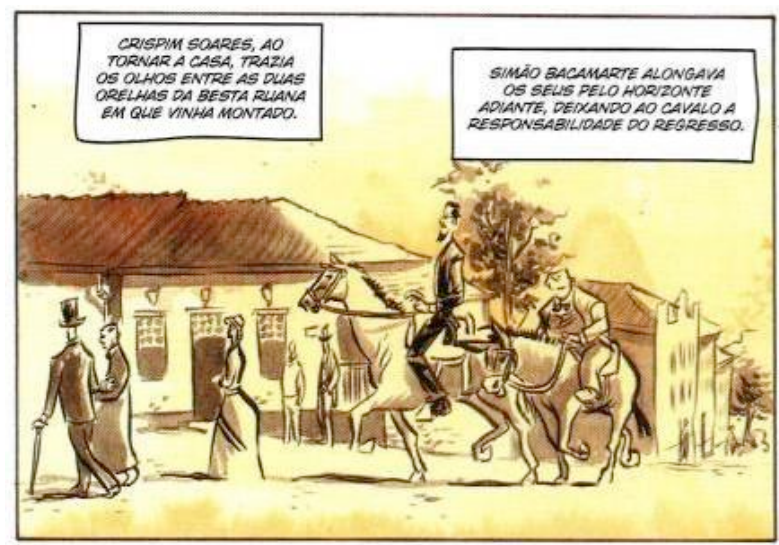

Figura 9: O Alienista. Quixotesco. (p. 20). 

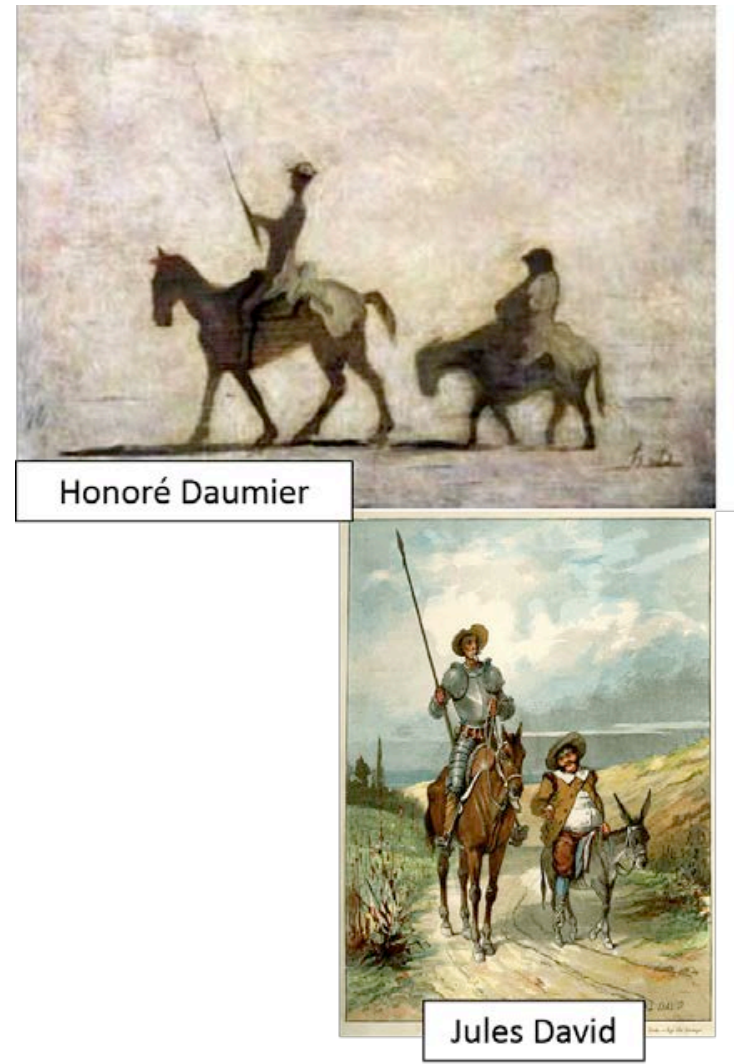
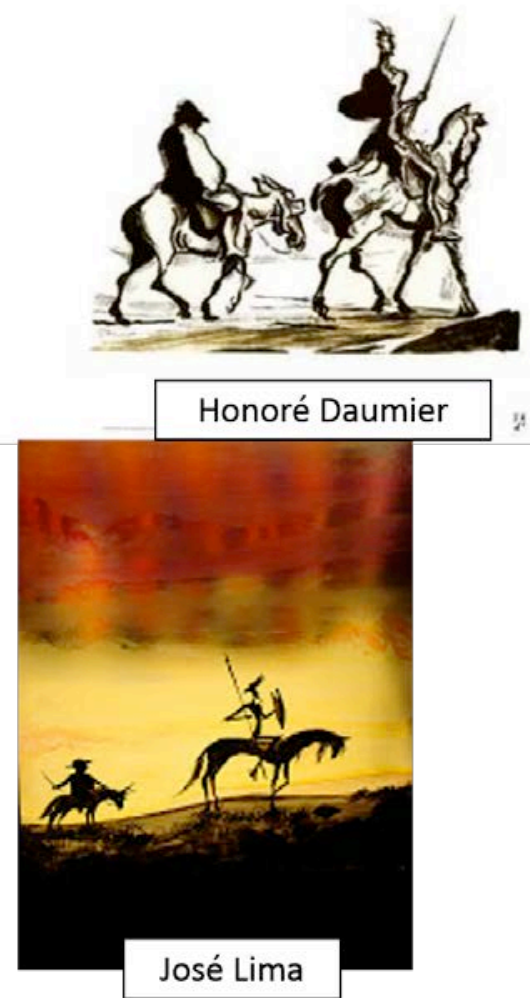

Figura 10: Representações de Dom Quixote. Diversos autores.

Há um estudo de Moisés (2001) que faz um paralelo d'O Alienista machadiano com a obra de Cervantes, Dom Quixote. ${ }^{8}$ A passagem que serviu de partida para o estudo de Moisés (2001) coincide com a passagem do conto machadiano:

E partiu a comitiva. Crispim Soares, ao tornar a casa, trazia os olhos entre as duas orelhas da besta ruana em que vinha montado; Simão Bacamarte alongava os seus pelo horizonte adiante, deixando ao cavalo a responsabilidade do responsabilidade do regresso. Imagem vivaz do gênio e do vulgo! Um fita o presente, com todas as suas lágrimas e saudades, outro devassa o futuro com todas as suas auroras. (ASSIS, 1977, p. 17-18).

A aparência de Simão Bacamarte na obra de Moon e Bá é puramente quixotesca: corpo delgado, cavanhaque, e sempre contrastante com a figura de um homem baixo e gordo. Isso vem mostrar que uma tradução é um exercício de leitura, ou, em outras palavras, "a tradução é crítica” (CAMPOS, 1976, p. 31), é a maneira mais atenta de ler. A direção em que aparentemente caminha a construção do personagem Simão Bacamarte no conto é do geral para o específico, ou seja, do tipo ${ }^{9}$

\footnotetext{
${ }^{8}$ À guisa de curiosidade, ao indagar a Fábio Moon se ele havia lido o estudo supracitado, sua resposta foi: "Não li esse estudo, mas enxerguei o paralelo durante a leitura do conto [...]. Acho que tanto Bacamarte como Quixote eram norteados pela loucura, uma loucura épica, e foi esse aspecto épico que eu quis passar para a adaptação.” (MOON, 2010, entrevistado por COSTA \& LOPES, p. 131).

${ }^{9}$ Tipo é o personagem paradigmático da ficção, que representa aspectos coletivos de personalidade. No caso do conto, tratava-se do modelo de cientista da época, que Machado soube satirizar. Hoje, figuras
} 
para o personagem com aprofundamento psicológico. O caminho que Moon e Bá aparentemente fizeram foi o inverso: a leitura d'O Alienista possibilitou decompor as características do personagem principal, equiparando-o a um tipo, representado hoje pela figura do Quixote, e aproximando essa figura da do cientista louco.

A afirmação de Moon sobre a escolha por uma imagem épica, grandiosa, da história reforça nossa suposição de que o personagem do alienista pode ser visto de muitas formas, de que ele assume várias faces ao longo da história, sobretudo na versão machadiana. Ora ele é visto como louco, ora como grande sábio, ora como um déspota. Loucura, ciência e poder. Se focarmos o louco, as características do erudito isolado e do governante tirano vêm reforçar aquela identidade. Se dermos atenção ao sábio, os traços de loucura se amenizam e a tirania toma ares de razão incompreensível pela população. Se construirmos o déspota, vemos como o poder sobe à cabeça e como o conhecimento é uma forma de poder. Essas são as identidades mais evidentes na obra.

Os procedimentos usados para qualificar o alienista são vários, e em sua maioria subjetivos, chegando mesmo a incorrerem em contradições, ambiguidades, e todo tipo de incertezas ao longo da história. No fragmento a seguir, por exemplo, Simão Bacamarte é ao mesmo tempo traiçoeiro e ilustre: "A notícia desta aleivosia do ilustre Bacamarte lançou o terror à alma da população.” (MOON \& BÁ, 2007, p. 26, grifo nosso).

O texto machadiano, muito presente na história em quadrinhos, põe em xeque aquele tipo de descrição objetiva e inquestionável de um personagem, pois o narrador machadiano reporta a opinião e as falas de inúmeros personagens e do discurso que ele leu nas crônicas de Itaguaí. O discurso de um narrador sobre um personagem tende a ser menos questionado se ele for um narrador heterodiegético e, consequentemente, extradiegético. Seu discurso é tido como verdade por ele aparentar saber de tudo, o que seria pura ingenuidade por parte de um leitor. O narrador machadiano não nos dá nenhuma certeza, só dúvidas.

Na graphic novel, a descrição do alienista é ainda mais questionável em termos de precisão, pois muito do que seria reportado pelo narrador é dito diretamente por um personagem, através dos balões de fala. Um personagem não pode, no universo diegético, saber de tudo. O que se conclui disso é que a descrição do Dr. Bacamarte, em seus aspectos morais, pelo menos, não é objetiva. Cada personagem teve dele uma visão, e que pôde ainda ser modificada ao longo da narrativa. Quem foi Simão Bacamarte? Um tirano, louco ou um grande sábio? Ele foi muitos sujeitos, e lhe foram atribuídas muitas máscaras. A ambiguidade machadiana cede lugar à ambiguidade de Moon e Bá, permanecendo abertas as possibilidades de interpretação.

\section{Enquadrando o(s) silêncio(s)}

A gama de empregos e possibilidades de uso do silêncio faz confirmar "que o silêncio é algo significante na vida e no discurso. O silêncio fala, significa. O silêncio é linguagem. Assim, a questão central levantada, aqui, é: como situar o silêncio no texto ficcional?” (MELLO, 2002, p. 87). Ou ainda, como o silêncio faz parte do discurso quadrinístico e como ele foi empregado no texto de Moon e Bá?

como o Quixote, Don Juan, Romeu podem se configurar como tipos similares àqueles do teatro de Gil Vicente. 
Mello (2002) ressaltou em seus trabalhos sobre o(s) silêncio(s) na literatura a fugacidade e efemeridade do silêncio. Seu trabalho partiu das manifestações do silêncio na tessitura linguística do texto literário. Nesses trabalhos, Mello (2002) se propôs a “dar um conteúdo linguístico ao silêncio [...]” (MELLO, 2002, p. 90). Para o texto literário, essa proposta é pertinente, mas nos parece que, para o texto quadrinístico, o conteúdo do silêncio não é de base linguística apenas (ou seja, na língua), embora ainda seja discursivo.

Nas artes verbovisuais ou audiovisuais, no entanto, o silêncio não é tão fugaz ou efêmero assim: suas marcas podem ser visíveis (como nas histórias em quadrinhos) ou "audíveis" (como no cinema). Nestes casos, a ausência da palavra e/ou do som (como forma do silêncio) conta com signos mais precisos para sua representação.

O silêncio pode se manifestar nos quadrinhos de inúmeras formas. De maneira geral, dizemos que se manifesta: (a) nas sarjetas, sendo este silêncio constitutivo da linguagem quadrinística; (b) nas reticências dentro dos balões de fala ou por meio de balões vazios, embora sejam recursos raros; (c) nos quadros sangrados, como forma de alusão ao que está fora da demarcação do quadro (fora da mancha gráfica), mas que tem existência presumida; (d) nos quadros mudos, apenas com recordatários, sobretudo nas combinações paralelas, em que a discrepância tempo-espacial entre palavras e imagens é maior; e (e) nos quadros silenciosos, sem falas de personagens e de narrador (sem recordatários). O silêncio n’O Alienista é um espaço diferenciado da produção de sentidos: é um espaço aberto, onde o leitor pode atuar com maior liberdade: cada leitor pode atribuir às marcas do silêncio sentidos diversos, de acordo com seu repertório pessoal de possibilidades.

Assim, vê-se que o trabalho de adaptação/tradução intersemiótica passa por uma negociação das partes que serão excluídas e transmutadas. O fragmento a seguir é a cena do suposto ciúme de Simão Bacamarte na ocasião das festividades de boasvindas de D. Evarista, que chegara do Rio de Janeiro. Durante o jantar, "D. Evarista foi o assunto obrigatório dos brindes, discursos, versos de toda a casta, metáforas, amplificações, apólogos”. (MOON \& BÁ, 2007, p. 33; ASSIS, 1977, p. 27). Diante de alguns elogios, que muito agradavam a D. Evarista, o Dr. Bacamarte teceu o comentário: “A retórica permite tais arrojos sem significação.” (MOON \& BÁ, 2007, p. 33). O último quadro da sequência de transições abaixo é silencioso, não tem narração nem diálogos, e ocorre após um elogio exacerbado do personagem Martim Brito a D. Evarista.
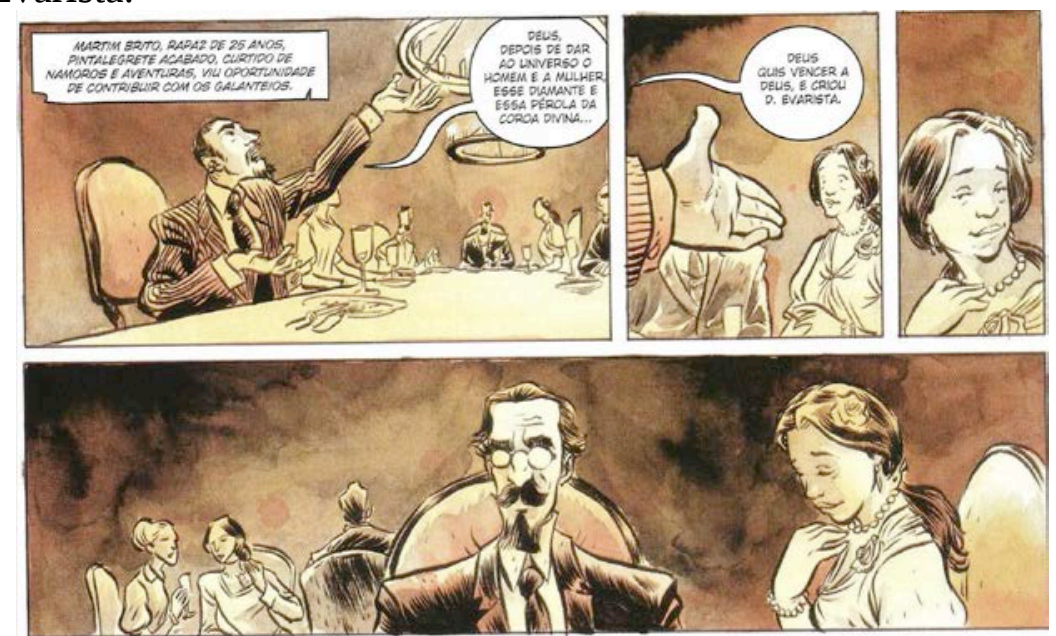

Figura 11: O Alienista. Gesto nublado. (p. 33). 
Antes de tudo, cabe distinguir, a partir de Bakhtin (2003), silêncio de quietude. Embora ambos incidam sobre uma ausência, o silêncio é a ausência da palavra, ele só se desfaz pela palavra. A quietude é a ausência de som. Algumas passagens da graphic novel podem significar de fato silêncio ou até quietude. Outras podem ser um silenciamento de passagens de uma cena em que haveria palavras, seja na narração ou nas falas de personagens. Seja como for, o uso do(s) silêncio(s) na história em quadrinhos denota uma intencionalidade, como no uso de reticências no texto literário. As reticências têm uma função singular no texto em relação aos outros sinais de pontuação. Elas podem ser uma intenção do autor. Uma omissão intencional de uma informação perceptível no mundo diegético, mas ofuscada ao leitor, negandolhe acesso a uma parte desse mundo.

A ausência da representação de som no último enquadramento não significa silêncio absoluto na cena, no universo contado. Vê-se, ao fundo, duas senhoras conversando, as mesmas que em cena posterior afirmarão que a atitude do alienista de prender Martim Brito na Casa Verde se deu por ciúmes. Analisando a cena isoladamente, o leitor pode ser levado a concordar com as senhoras na cena ulterior. Mas, considerando as razões que levaram Bacamarte a se casar com D. Evarista, e o comportamento racional do alienista, cabe perguntar: Simão Bacamarte sentiu ciúmes ou não? Ou o gesto oblíquo, nublado, silencioso, seria a constatação de mais um louco de Itaguaí diante dos seus olhos? Eis um efeito de sentido que um quadro silencioso é capaz de perpetuar: a dúvida.

A forma do quadro, que também é um recurso utilizado pelo quadrinista (o autor-escritor), interfere também na leitura do tempo e do sentido do silêncio. Sendo um quadro alongado, sua forma visa direcionar o olhar do leitor pelo seu conteúdo por mais tempo, indo de um lado ao outro da mancha gráfica. Nos quadrinhos, o tempo (representado no interior dos enquadramentos) e o espaço (da página, ocupado por diferentes formas de quadros) estão intimamente ligados, sendo a mesma coisa (McCLOUD, 1995). Ao sugerir a demora na leitura do enquadramento, o autorescritor convida o leitor a divagações sobre a situação representada.

Elementos plásticos assumem conotações à medida que a cena é interpretada: as manchas escuras espalhadas pelo fundo da imagem podem ser interpretadas como sinal negativo, indicativos de que a atmosfera emocional ficou carregada. O plano médio frontal com a figura de Bacamarte centralizada dá seriedade e gravidade à sua expressão. D. Evarista é colocada como signo secundário, e, ao fundo, as duas mulheres conversando são signos em posição terciária. Elas são indicativos de que outros sentidos estão latentes, mas circundantes ao sentido da figura de Simão. O homem sentado à direita de Simão (Q1) é omitido no Q4: seu significado não podia concorrer com o de D. Evarista.

Mais do que evidenciar aspectos textuais, devemos lembrar que os personagens são signos complexos: sua significação é mutável e está atrelada às funções que desempenham na trama. Cabe indagar: numa cena cujo ponto de atenção era D. Evarista, por que os signos plásticos se convergiram para o signo icônico do personagem Simão Bacamarte, sem qualquer menção verbal por parte do narrador? O que se passou na mente de Bacamarte que justificasse a articulação do texto da maneira que se deu? Como outros escritores de ficção, os quadrinistas usam o silêncio "dando-lhe forma como opção de linguagem e construção de sentidos para caracterizar um mundo interior onde as palavras, ou melhor, a linguagem, não dá conta de dizer os sentidos.” (MELLO, 2002, p. 120). 
O quadro silencioso faz surgir a possibilidade de sentidos pela omissão de outros já configurados no texto machadiano. Silenciar Machado é condição ínsita para fazer falar Moon e Bá. "Dessa concepção de silêncio como condição [e possibilidade] de significação, resulta que há uma incompletude constitutiva da linguagem quanto ao sentido.” (ORLANDI, 2007, p. 69). Busca-se desfazer essa incompletude na relação do Mesmo com o Outro. Essa incompletude aponta para a primazia do interdiscurso, e "não deve ser vista como falta, mas como horizonte." (MELLO, 2002a, p. 289). O quadro silencioso acima coincide com o ponto do texto machadiano que recortamos:

D. Evarista baixou os olhos com exemplar modéstia. Duas senhoras, achando a cortesanice excessiva e audaciosa, interrogaram os olhos do dono da casa; e, na verdade, o gesto do alienista pareceu-lhes nublado de suspeitas, de ameaças e provavelmente de sangue. $\mathrm{O}$ atrevimento foi grande, pensaram as duas damas. E uma e outra pediam a Deus que removesse qualquer episódio trágico - ou que o adiasse ao menos para o dia seguinte. Sim, que o adiasse. Uma delas, a mais piedosa, chegou a admitir consigo mesma que D. Evarista não merecia nenhuma desconfiança, tão longe estava de ser atraente ou bonita. Uma simples água-morna. Verdade é que, se todos os gostos fossem iguais, o que seria do amarelo? Esta ideia fê-la tremer outra vez, embora menos; menos, porque o alienista sorria agora para o Martim Brito [...]. (ASSIS, 1977, p. 28, grifos nossos).

Nublados de suspeitas parecem ser os comentários que o narrador faz no conto. O narrador tem a capacidade onisciente de dizer o alvoroço mental pelo qual as convidadas passavam, mas não diz uma só verdade onisciente sobre a figura do alienista. Aliás, essa é uma característica do narrador que permeia todo o conto, segundo já nos afirmou Garbuglio (1977) sobre a caracterização de Simão Bacamarte, que evita expansões sentimentais inexistentes no personagem. Tal como ocorre no conto, o gesto do alienista na graphic novel se presta a interrogações: esse gesto não $e ́$, na plenitude objetiva do ser que poderíamos afirmar na fala de um narrador onisciente em terceira pessoa. Esse gesto só parece.

O Q4 da p. 33 traduz uma parte do excerto machadiano equivalente. Nesse sentido, certos signos estão ancorados uns aos outros. Por outro lado, no mesmo excerto há sentidos que de forma alguma foram representados, de modo que uma outra camada de sentido permaneça em revezamento com o Q4.

\section{Considerações finais}

Por muitos motivos, diríamos que O Alienista de Moon e Bá é o mesmo Alienista de Machado. O mesmo, pois não há como negar a presença de Machado, sua presença se impõe a partir de seu nome na capa. Mas diremos que O Alienista de Moon e Bá é outra obra. É um Alienista outro, pois a situação de comunicação, as condições de discurso, o contexto são outros (as palavras machadianas deixam de ser palavras machadianas à medida que não mais respondem ao paradigma científico do séc. XIX e são (re)configuradas pelo discurso quadrinístico, alterando o estatuto dos sujeitos envolvidos, a ancoragem social da obra e, evidentemente, as marcas formais do texto (CHARAUDEAU, 2004)). Devemos evitar uma confusão: enquanto outro Alienista, a obra de Moon e Bá é o Mesmo. O seu Outro, trazido no fio discursivo, é a obra de Machado (AUTHIER-REVUZ, 1990). 
Machado estava inserido em um sistema de valores que pregava certas regras de escrita, de comportamento, de crenças, de ideologias, etc. Sua atitude com $O$ Alienista foi, minimamente, em resposta a uma parte desse sistema de valores. Podemos dizer que a preocupação de Machado foi, em parte, criticar tal sistema. A preocupação de Moon e Bá não pode ter sido essa, pelo menos não é isso que o(s) texto(s) nos $\operatorname{diz}(\mathrm{em})$ - sua obra, suas entrevistas, as críticas. O sistema de valores de Moon e Bá é outro, pois sua obra está, antes de tudo, ancorada à instituição discursiva quadrinística (COSTA, 2013). Se há uma crítica, certamente ela não se apropria do mesmo discurso machadiano (mas sim do mesmo texto), pois sua utilidade é outra. A crítica de Moon e Bá se utiliza dos meios quadrinísticos, inseridos em sistemas de valores próprios, e só aponta indiretamente para os sistemas de valores que $O$ Alienista machadiano critica.

Podemos substituir a noção reducionista de sistema de valores pela de campo discursivo. Por sua ligação com a Literatura, Moon e Bá podem falar para dois campos: o literário e o quadrinístico. Porém, só podem falar situados em um desses campos: o quadrinístico. Falar para a Literatura sem se situar no campo literário pode parecer uma contradição ou inconsistência teórica. Mas, por meio do interdiscurso, acaso não seria possível os Quadrinhos dizerem algo à Literatura?

Constatamos que a análise em torno da relação entre palavras e imagens nas histórias em quadrinhos é distinta da análise de uma publicidade de massas Panzani, por exemplo, pois são distintos os usos que se fazem desses signos. Constata-se também que a presença do Outro na tradução intersemiótica é um processo dialético que consiste em renovar não apenas o sentido do Outro no Mesmo, mas também os sentidos do Outro em seu próprio sistema. Como vem dizer Bassnett (2003, p. 61): “[...] o tradutor pode por vezes enriquecer ou esclarecer o texto original como resultado direto do processo de tradução”. A marca autoral de Moon e Bá se instala no limiar dessa renovação, na possibilidade subjetiva, situacional, sócio-histórica de novos sentidos.

Lucas Piter Alves Costa

johannlufter@yahoo.com.br

Pós-Graduação em Estudos Linguísticos - UFMG

\section{Referências}

ASSIS, M. O alienista. 5a ed. São Paulo: Ática, 1977.

AUTHIER-REVUZ, J. "Heterogeneidade(s) enunciativa(s)". In: ORLANDI, E. P.; GERALDI, J. W. (Orgs.). O discurso e suas análises. Cadernos de Estudos Linguísticos, n. 19. Campinas, SP: UNICAMP/IEL, 1990, p. 25-42.

BÁ, G. Profissão: quadrinhista. 10 Pãezinhos. 2007. Disponível em: <http://10paezinhos.blog.uol.com.br/arch2007-05-01_2007-05-31.html>. Acesso em: 03 out. 2012. 
BAKHTIN, M. Estética da criação verbal. Introd. e trad. do russo Paulo Bezerra. $4^{\text {a }}$ ed. São Paulo: Martins Fontes, 2003.

BASSNETT, S. Estudos de tradução: fundamentos de uma disciplina. Trad. Vivina de Campos Figueiredo. Lisboa: Fundação Calouste Gulbenkian, 2003.

BREMOND, C. "Para um gestuário da banda desenhada". In: GREIMAS, A. G.; KRISTEVA, J.; BREMOND, C. (Orgs.). Práticas e linguagens gestuais. Trad. Manuela Torres. Lisboa: Editorial Vega, 1979, p. 135-144.

CAGNIN, A. L. Os quadrinhos. São Paulo: Ática, 1975.

CAMPOS, H. Metalinguagem: ensaios de teoria e crítica literária. São Paulo: Editora Cultrix, 1976.

CHARAUDEAU, P. "Visadas discursivas, gêneros situacionais e construção textual”. In: MACHADO, I. L.; MELLO, R. (Orgs). Gêneros: reflexões em análise do discurso. Belo Horizonte: NAD/FALE/UFMG, 2004, p. 13-41.

CHARAUDEAU, P. « Les stéréotypes, c'est bien, les imaginaires, c'est mieux ». In: BOYER, Henri (Org). Stéréotypage, stéréotypes: fonctiontionnements ordinaires et mises en scène. Paris: L'Harmattan, 2007, p. 49-63.

COSTA, L. P. A. Uma abordagem semiolinguística da narrativa: o "tempo narrativo" na instituição literária. 2010. 72 p. Monografia (Licenciatura em Letras) Universidade Federal de Viçosa, Minas Gerais.

COSTA, L. P. A. O Alienista, de Fábio Moon e Gabriel Bá: uma análise do discurso quadrinístico. 2013. 213 f. Dissertação (Metrado em Letras). Universidade Federal de Viçosa, Viçosa, Minas Gerais.

COSTA, L. P. A.; LOPES, E. C. A contribuição das histórias em quadrinhos nas análises literárias: O Alienista, de Machado de Assis, em graphic novel. Relatório Final de Pesquisa de Iniciação Científica. Universidade Federal de Viçosa, Viçosa, MG, 2009.

ECO, U. Apocalípticos e integrados. São Paulo: Editora Perspectiva, 1979.

EISNER, W. Quadrinhos e arte sequencial. $3^{\mathrm{a}}$ ed. Trad. Luís Carlos Borges. São Paulo: Martins Fontes, 1999.

GARBUGLIO, J. C. “Apresentação”. In: ASSIS, M. O alienista. São Paulo: Ática, 1977, p. 5-8.

GOMES, P. E. S. “A personagem cinematográfica”. In: CANDIDO, A. et al. A personagem de ficção. São Paulo: Perspectiva, 2004, p. 103-119.

JOLY, M. Introdução à análise da imagem. Trad. Marina Appenzeller. São Paulo: Papirus Editora, 2007.

KRESS, G.; van LEEUWEN, T. Reading images: the grammar of visual design. New York: Routledge, 2006.

LIMA, L. C. “O palimpsesto de Itaguaí”. In: demanda II). Rio de Janeiro: Rocco, 1991, p. 253-265.

MAINGUENEAU, D. Novas tendências em análise do discurso. Trad. Freda Indursky. Campinas, SP: Pontes, Editora da UNICAMP, 1997.

McClOUD, S. Desvendando os quadrinhos. Trad. Helcio de Carvalho, Marisa do Nascimento Paro. São Paulo: Makron Books, 1995.

McClOUD, S. Desenhando quadrinhos. Trad. Roger Maioli dos Santos. São Paulo: Makron Books, 2008.

MELLO, R. “Análise discursiva do(s) silêncio(s) no texto literário”. In: MACHADO, I. L.; et alii. Ensaios em análise do discurso. Belo Horizonte: FALE/UFMG, 2002, p. 87-123. 
MOISÉS, M. “'O Alienista’: paródia de Dom Quixote?” In: MOISÉS, M. Machado de Assis: ficção e utopia. São Paulo: Cultrix, 2001, p. 127-140.

MOON, F. As próximas duas semanas. 10 Pãezinhos. 2006. Disponível em: $<$ http://10paezinhos.blog.uol.com.br/arch2006-10-01_2006-10-31.html>. Acesso em: 03 out. 2012.

MOON, F. Sob os quadros da Casa Verde: uma entrevista com Fábio Moon. Depoimento [2010]. Opiniães. Entrevista concedida a COSTA, L. P. A.; LOPES, E. C.

MOON, F.; BÁ, G. O Alienista: Machado de Assis: adaptação em quadrinhos. Rio de Janeiro: Agir: 2007.

NUNES, B. O tempo na narrativa. São Paulo: Editora Ática, 1988.

ORLANDI, E. P. As formas do silêncio: no movimento dos sentidos. $6^{\mathrm{a}}$. ed. Capinas, SP: Editora da Unicamp, 2007.

PEASE, A.; PEASE, B. Desvendando os segredos da linguagem corporal. 4. ed. Rio de Janeiro: Sextante, 2005.

RAMOS, P. A leitura dos quadrinhos. São Paulo: Editora Contexto, 2010.

REIS, C.; LOPES, A. C. M. Dicionário de teoria da narrativa. São Paulo: Editora Ática, 1988. 